\title{
EXPLOITATION OF MARINE SWIMMING CRAB IN COX'S BAZAR, BANGLADESH
}

\author{
Bikram Jit Roy*, Nripendra Kumar Singha, S.M. Hasan Ali \\ and Md. Gaziur Rhaman \\ Marine Fisheries Survey Management Unit, Chittagong, Bangladesh
}

Bangladesh is rich in biological diversity. Among the marine species, crab is one of the important commodities which earn foreign currency for the country. The harvesting of swimming crab could play an important role in enhancing protein production, foreign currency earnings and internal trade development. It could also help to create employment opportunities for the unemployed and underemployed fishermen in the coastal areas at Shahparir dwep, Teknaf sadar, Shamlapur, BFDC fish landing center and Moheskhali in Cox's Bazar district for five to six months. The crab harvesting is a new alternative livelihood and have a great prospect in Bangladesh; however, it has not yet been established in the country. Crab export was started in the country in 1977-78 and became a stable business in 1982 and ranked third among frozen foods that were exported for earning foreign currency (Ali and Rahman 1986).

In 2008 total commercial crab production was $1,319,953$ metric tons (MT) in the world (FAO 2008). In the year 2009-2010, the total crab production of Bangladesh was 7707.70 MT which is less than $1.0 \%$ of the world crab production; Total exported quantity was 6347.70 MT from which the total earnings of foreign currency was 3758.8 million taka and exporting countries were China, Japan, Korea and Taiwan (Anon. 2011). Mainly three crab species (mud crabs, Scylla serrata; three spot swimming crabs, Portunus sanguinolentus (Herbst. 1783) and blue swimming crabs, Portunus pelagicus (Linnaeus, 1758) are exported from Bangladesh. Among them blue swimming crabs are costly and great demand in the international market for its quality meat.

Bhuiyan and Das (1976) made a taxonomic investigation and reported 15 species of crab from the intertidal zone. Mahmood (1977) reported $16 \mathrm{crab}$ species of the coast of Bangladesh. Four species inhabit in fresh waters and 11 species inhabit in marine waters (Ahmed 1991). Among the marine crab species only three species of marine swimming crabs, viz. blue swimming crabs, three spot swimming crabs are abundantly available and the cross crabs, Charybdis feriatus (Linnaeus, 1758) are found incidentally in the Bay of Bengal. In the total catch more than $80 \%$ are blue swimming crabs. Only mud crab (S. serrata) and swimming crab ( $N$. pelagicus) are consumed in Bangladesh (Islam 1977). Most of these harvested crabs are usually transported from Cox's Bazar to Dhaka for

*Author for correspondence. E-mail: jitroy1964@yahoo.com 
export and other species are usually used to make fish meal, poultry meal etc. (Mithun 2010).

The present study was conducted from March to August 2011 at different landing centres in Cox's Bazar district to assess the feasibility of swimming crabs exploitation and marketing system, local community participation and interest, crab harvesting, and sustainable utilization of these resources.

The samples and data were collected from five landing centers at Shahparir dhip, Teknaf sadar, Shamlapur, Moheskhali and Cox's Bazar BFDC landing center in Cox's Bazar district. More than 500-600 numbers of boat typically 8.0-9.0 meters long and 2.13 to $2.50 \mathrm{~m}$ wide and having engine horse power ( $\mathrm{hp}$ ) ranging from $20 \mathrm{hp}-22 \mathrm{hp}$ engaged for marine crab fishing. The numbers of fishermen on each boat were 6-7 and active fishing per month was 25-27 days. The crabs exploiting boats were going away 4.0-4.5 hours from the shore of the west side of Teknaf and all are engaged for daily fishing. The most common type of commercial fishing gear for the swimming crab species is Jew fish or Croaker fish catching net which is monofilament modified small mesh drift gill net (SMD). The total length was about $3000-4000 \mathrm{~m}$, depth from 2.75 to $3.57 \mathrm{~m}$, and mesh size of 5.0-5.2 cm. Another type of crab fishing gear was crab pot, which was a rectangular bamboo-made trap with two entrances and height was $60 \mathrm{~cm}$ and width $40 \mathrm{~cm}$; it was used in bottom and fixed with a rope. This crab pot was used as a gear by less than $5 \%$ fishermen. And sometimes the carbs were caught incidentally by the marine set bag nets and trawl nets. The swimming crab species are harvested commercially mainly in the full moon period by artisanal fishing. Sampling was carried out around the year by the Marine Fisheries Survey Management Unit, Chittagong. But, the main harvesting period of swimming crab was from March to August. The study was based on total landing of questionnaire survey, information through a sample survey among crab aratders (depot owners/ assemblers) and crab collectors where five crab aratders were conducted. The collected data were processed and analyzed using Microsoft Excel.

A total of three species of Marine swimming crab species was identified in the study period. Among them the most common two species were the blue swimming crab $P$. pelagicus and Three spot swimming crab $P$. sanguinolentus and the cross crab $C$. feriatus was found incidentally in our marine fleets.

During March 2011 through August 2011 total 74.650 MT of swimming crabs (blue swimming crabs and three spot swimming crabs) were exploited from the selected five landing centers at Cox's Bazar district. The highest total landing of the swimming crabs was $23.480 \mathrm{MT}$ in BFDC landing center and the lowest was 8.520 MT in the Shaparir dwep during the same period (Table 1). The 
maximum and minimum landing of the swimming crabs were $6.00 \mathrm{MT}$ and 0.500 MT, respectively between May and August 2011.

The ghatwise maximum and minimum landing were $2.82 \mathrm{MT}$ and $0.50 \mathrm{MT}$, respectively at Shaparir dwep between May and August; 4.35 MT and 2.60 MT, respectively at Shamlapur during May and August; 6.00 MT in May and 2.20 MT in August, respectively at BFDC landing center; 2.80 MT in May and 0.50 MT in August, respectively at Moheskhali landing center; 3.400 MT in May and 1.12 MT in March 2011 at Teknaf sadar (Table 1).

Table 1. Monthwise total landing (MT) of swimming crab at different landing centers between March 2011 and August 2011.

\begin{tabular}{lllllll}
\hline Name of the landing center & March & April & May & June & July & August \\
\hline Shahparir dwep & 0.800 & 2.000 & 2.820 & 1.800 & 0.600 & 0.500 \\
Teknaf Sadar & 1.120 & 2.800 & 3.400 & 2.280 & 2.000 & 1.400 \\
Shamlapur & 2.800 & 3.6000 & 4.350 & 4.200 & 2.750 & 2.600 \\
BFDC, Cox's bazar & 2.500 & 5.210 & 6.000 & 4.310 & 3.260 & 2.200 \\
Moheshkhali & 1.400 & 2.000 & 2.800 & 1.850 & 0.800 & 0.500 \\
\hline
\end{tabular}

The highest catch per boat per day (CPUE) landing was $1.81 \mathrm{~kg}$ in Teknaf sadar landing center in May and the lowest CPUE was $0.18 \mathrm{~kg}$ in August in the Shahparir dwep (Table 1). The highest percentage composition of swimming crab was $34.65 \%$ in July at BFDC landing center, and the lowest was $6.38 \%$ in July at the same landing center.

Ghatwise average highest percentage composition was 31.45 in BFDC landing center and the lowest was 11.41 at Shaparir dwep landing center (Fig. 1a). In monthwise highest and lowest average percentage compositions of total landing were 25.95 and 9.65 in the months of May and August, respectively (Fig. 1b). During March through August some fishermen were engaged them permanently in crab harvesting and some fishermen occasionally went for crab fishing. In each selected swimming crab market, a number of depots was permanently engaged in crab trading for five to six months in each year. In Cox's Bazer district, the existing marketing system was started by the crab collectors. From collectors to the exporters, there exists a small marketing chain with 3-4 numbers of middle-men. The collected total crabs were supplied to Dhaka for export. So, a potential marketing system exists here.

Aratders (depot owners) usually buy crabs and sell them after grading. Usually, five grades are selected for blue swimming crabs as $\mathrm{XL}, \mathrm{L} / \mathrm{LM}, \mathrm{M} / \mathrm{MM}$, SM and SSM which represent the weights in grams of 500+, 400+, 300+, 200+ and $100+$, respectively. And for three spot swimming crabs, the grades were FF1, F1, F2 and F3 that represent the relative weights in grams of 200+, 180+, 
$150+$ and $100+$, respectively. In case of blue swimming crabs the first four grades and for three spot crabs the first three grades are bought from the collectors and prepared for sale. The other grades were usually sold to the local market for local consumption.
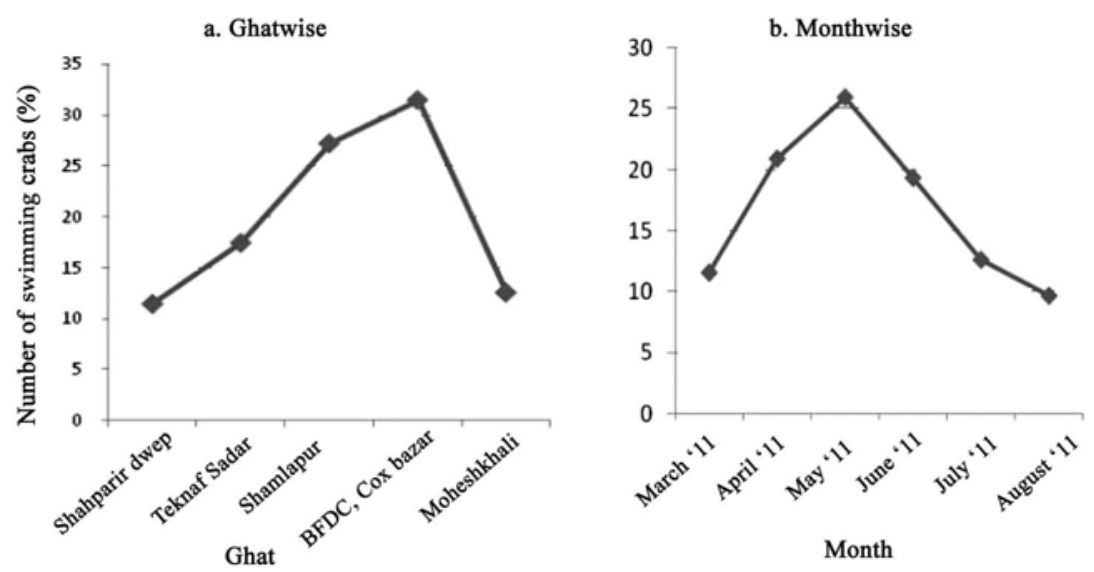

Fig. 1a,b. Ghatwise and monthwise composition of swimming crabs by weight at different landing Centers during March - August 2011.

In April through July the crabs migrate to the upward from the deep sea and are caught by the local fishermen in their SMD and traps. When rainfall is in peak then the collection of the crabs in this area is higher and heavier in weight. From May to July is the peak time of the year to catch large and heavy swimming crabs which constitute about $60-70 \%$ females of the total catch. In the total catch, more than $85-90 \%$ was blue swimming crabs which were found from April to July and their average weight was more than $400 \mathrm{~g}$ and the rest 10-15\% were three spot swimming crabs and their weight ranged 150-200 g. From August to early September, the catch of three spot swimming crabs was slightly increasing, but not more than $30 \%$ of the total catch. Among the total harvesting, $15-25 \%$ crabs were under-sized. This under-sized swimming crabs comprised of 30-80 $\mathrm{g}$ for males and 40-90 $\mathrm{g}$ for females in individual weight.

The exploiting of these crabs showed a usual upward trend in full moon time and downward trend in new moon. In our artisanal fishing all swimming crabs exploited within 40 meter depth zone of marine fleets. Maximum swimming crabs were harvested in the Elephant point area (middle of South of South Patches and South Patches). Portunus sanguinolentus catches were poor from September to November. Similarly, for P. pelagicus, fishing is extended from September to late May or early June.

Crabs are landed mainly as a by-catch of trawlers. Indigenous gears, such as gill nets and traps are also used to exploit the resource and mostly caught from 
a depth of about 10-60 meters (Manisseri and Radhakrishnan 2004). Crabs can be caught during all twelve months, but become inactive in winter when water temperature falls below $10-13^{\circ} \mathrm{C}$. As temperatures rise in March and April, catching rates increase rapidly (Whitaker 2010).

Present studies indicate that the tendency of the female crabs grows relatively heavier and higher number than the males under the family Portunidae, which is in conformity with the earlier observations in P. pelagicus and $P$. sanguinolentus.

\section{LITERATURE CITED}

AHMAD, K. 1991. Mud crab, a potential aquaculture resource of Bangladesh. In: The mud crab (ed. C.A, Angell). 161 pp.

ALI, M.H. and RAHMAN, M.I. 1986. An investigation on some socio-economic and Technical problems in pond fish culture in two districts of Bangladesh. J. Bangladesh Aquacult. 8(1): 47-51.

ANON. 2011. Mashik Matshya O Prani Samphad Barta (Bangla). No. 6, July-August 2011. Fisheries and Livestock Information Department, Matshya Bhaban, Dhaka-1000.

DAS, H.P. 1978. Studies on the Grey Mullet, Mugil cephalus (Linnaeus) from the Goa waters. Ph.D Thesis, University of Bombay, $223 \mathrm{pp}$.

FAO. 2008. Global Aquaculture Production in 1994-2008. Food and Agriculture Organization of the United Nations (FAO), Fishery Department.

MAHMOOD, N. 1977. Crustacean fauna of the Bay of Bengal of the coast of Bangladesh. Paper presented at the Biol. Workshop organized by Bangladesh Nat. Commission for UNESCO. 6 p.

MANISSERI, M.K. and RADHAKRISHNAN, E.V. 2004. Status of Exploitation Marine Fishery Resources of India ( Indian Council of Agricultural Research), Kochi-682014, India.

ROY, M. 2010. Feasibility study of mud crab (Scylla serrata) fattening in the mid coastal area of Bangladesh. pp.

WHITAKER, J.D. 2010. Marine Resource Division. The S.C. Department of Natural Resources Prohibits discrimination, P.O. box 167, Columbia, South Carolina 29202. 